\title{
A PRELIMINARY INVESTIGATION OF GYPSUM BONDED MOULDS BY THREE DIMENSIONAL PRINTING
}

\author{
S. S. Bobby ${ }^{1}$ \\ ${ }^{I}$ Research Scholar, School of Engineering, AUT University, Auckland, New Zealand
}

\begin{abstract}
Gypsum is used as binder in traditional moulding sand system for non-ferrous casting. New Zealand silica sand is the best sand as near white, high purity (silica 99.32\%) can be used for foundry application. An attempt has been made to use this material system in 3DP systems to study the behaviour and suitability to print moulds for non-ferrous casting with and without coating application at various baking conditions. The result shows that the importance of the calcination and the relation between the density and porosity, when density increases the mould strength increases but the porosity decreases and it is understood that the baking temperature and the type of coating influence the surface roughness. The dimensional error result shows the percentage swelling and shrinkage errors which is non-linear, but the result shows $0.5 \%$ shrinkage in lateral axis, $1 \%$ in horizontal axis, and $5 \%$ in vertical axis. Based on the volume the average error is been drastically reduced from $64.5 \%$ to $6.5 \%$. These result shows that the mould shrinkage can be reduced by further optimizing the baking condition and or adding suitable additives. There were no casting defects like mould wash, mould burn or distortion, and etc. It shows that the gypsum bonded mould have enough mould strength for casting at various conditions. In general surface roughness is the main concern in sand casting, it can be improved by adding suitable additives and coatings. Compare with two bench marked values the tensile strength value is higher and it's proved that the locally available material system used to print moulds by 3DP is not an inferior with commercially available material system.
\end{abstract}

Keywords: Sand casting, 3DP, Silica Sand, Gypsum

\section{INTRODUCTION}

Sand casting is an age old manufacturing process that has been around thousands of years. The Mesopotamians utilized it to their advantage to cast bronze and copper, since 4000 BC. It has a revolutionary change of casting from a few grams weight of sword to weight in tons of modern equipment's and parts. There is no place can find without a part or an equipment produced by casting say Automotive industry, Aerospace, Agriculture, Medical and etc. Most of the sand casting use green sand and its typically having the composition of $80 \%$ silica sand, $5-10 \%$ clay binders, $2-6 \%$ water for tempering the mixture and variety of additives mixed together based on the application, sand casting is mostly used for high volume production [1]. Today, more than $60 \%$ of metals produced around the world are manufactured using sand casting process [2]. The expected market growth of sand casting in US alone would be 42.6millions in the year 2015 [3] and annual tons shipped per casting facility will increase from 2,100 tons per year to 2,500 tons. Aluminum casting and ductile iron casting shipments are forecast to grow to 13 million tons and 23 million tons respectively [4]. Sand casting has great flexibility, economy; least costly however it has its own limitations of casting thin long projections, moisture in the sand, dimensional accuracy, surface finish, complexity of cast design and the lead time. The answers to some of these issues arise out of developments taking place in a different area; Rapid prototyping / tooling / manufacturing. There are various RP processes (SLA, SLS, DMLS, 3DP, Etc.) are developed to fabricate the patterns and moulds with lesser time and any complex shapes [5]. Each process has its own advantages and limitations among the RP processes considering the cost, lead time and the flexibility of the system, among the RP systems 3DP is a simple and user friendly system used for sand casting.

The Three Dimensional Printing (3DP) based on the MIT's (Massachusetts Institute of Technology) ink- jet technology under U.S patent no US005340656 [6] and utilized by ZCorporation in a variety of printers is considered to be one of the most future oriented rapid prototyping (RP) system. It is classified as a typical "concept modeler", a low end system, and represents the fastest RP - process. This 3DP technique based on layer by layer manufacturing is extending their fields of application, far beyond the original idea of generating design iteration. The applications have been extended from the building of aesthetic and functional prototypes to the production of tools and moulds for technological prototypes or pre-series [7]. Mould produced by $3 \mathrm{DP}$ and pouring the molten metal in to cavity by traditional process is called Rapid Casting. Computer controlled continuous-jet print head is raster scanned over each layer of powder, individual lines are added together to form 2D layers, and the 2D layers are added together to form a 3D part by moving the piston downwards, i.e. Length and width of the part is been formed in ' $x$ ' and ' $y$ ' direction by the moving ink-jet print head and the height of the part is controlled by a lowering piston in z-direction, controlled by a computer. Unbound powder temporarily supports unconnected portions of the parts, allowing overhangs, undercuts and internal volumes to be created. The unbound 
powder is removed by powder removing process [8]. 3DP technology with the use of a ceramic material allows the production of complex cavities, suitable for casting light alloys [9].

Traditional sand mould process uses almost all the sands which are having high refractoriness and cohesiveness etc. mixed with various binders and additives. Where as in use of sand materials in the printer have some limitations. EXONE printers from Germany uses furan resin coated sand with an active agent and binder in their system to produce sand moulds to cast both ferrous and non-ferrous material systems [10] and Z Corporation printers from USA uses plaster-ceramic composite suitable for casting low temperature $\left(1100^{\circ} \mathrm{C}\right.$ ) metals (Aluminium, Magnesium, and Zinc) [11]. Z Corporation supplies two types of powder materials ZP 131 and Zcast 501 to use in their Z printers. ZP 131 is designed for basic prototyping and fine art modelling while Zcast 501 is for non-ferrous casting mould fabrication. Molecular formula of ZP131 is $\mathrm{Ca}(\mathrm{SO} 4) \cdot 0.67(\mathrm{H} 2 \mathrm{O})$ this chemical composition is almost identical to that of Calcium Sulphate Hemihydrate, also known as Plaster of Paris or Gypsum Plaster. While the Zcast 501 molecular formula is $\mathrm{Ca}(\mathrm{SO} 4) .0 .67(\mathrm{H} 2 \mathrm{O})(50 \mathrm{wt}$ $\%)+\mathrm{MgSiO} 4(50 \mathrm{wt} \%), \mathrm{MgSiO} 4$ is a variation of Olivine sand, thus Zcast 501 powder material is a mixture of Gypsum plaster and Olivine sand [12] and the following components are in its Gypsum (CaSO4.2H2O), Calcium Silicate $\mathrm{Ca} 2(\mathrm{SiO} 4)$, Calcium Calcite (Ca CO3), Magnetite (Fe3 O4), Olivine (MgFe)2 (SiO4), Forsterite (Mg2SiO4), Magnesite $(\mathrm{MgCO} 3)$ and some other compounds but no quartz sand ( $\mathrm{SiO} 2$ ) was found [16]. The $\mathrm{Z}$ Cast mixture has increased humidity and strength but lower gas permeability compared with the standard sand-gypsum mixture [13-15]. Since the available sand materials system are very limited and proprietary also and researchers have no freedom to play around those system to understand the behaviour at various conditions. The aim of the current research is to understand the behaviour of the various material systems at various conditions in regards to cast quality but is considerably less expensive and fabricated from domestic components [16].

\section{SELECTION OF THE MATERIAL SYSTEM}

The basic properties required in moulding sand are refractoriness, permeability, cohesiveness, green strength, dry strength, flowability or plasticity, adhesiveness \& collapsibility and its coefficient of thermal expansion should be low. In green sand, mould sand (Silica, Zircon, etc.) accelerates the refractoriness; binder (Bentonite, Gypsum, etc.) develops the bonding among the sand particles to retain sufficient green and dry strength, Additives (organic or chemical) holds the plasticity and water promotes cohesiveness. The material system used in 3D Printing should be water free or less moisture for easy to spread by the roller. The unbounded particles should be free from absorbing moisture from neighboring particles while the print head strikes the liquid binder on the surface of the powder bed and to act as a support structure for the overhanging's and cavity regions.
As soon as liquid binder strikes the powder surface the additives present in the material system should trigger the binding mechanism to bind the particles and harden within the selected region as per the diagram at the same time the previous layer should easily accept the fresh layer without producing any stair case effect while printing the entire shape and size of the mould. The binder and additives together accelerates the bonding mechanism for the green strength and cohesiveness of the mould and the sand particles retains the refractoriness or hot hardness. Different types of refractory sands used for sand moulds are Silica sand, Zircon sand, Silimanite, Olivine and Graphite/carbon. Out of which Silica sand is most widely used in foundries because of the following: It is a very good refractory material and does not fuse or soften even at very high temperatures, i.e. $1650{ }^{\circ} \mathrm{C}$, which in contact with molten metal $[17,18]$. They can be easily moulded into intricate shapes. They have sufficient porosity or permeability and allow easy escapes of gases produced by molten metal and other bonding constituent. They can be used repeatedly for making moulds after addition of some bonding materials. They are cheap and easily available, chemically immune to molten metals and they don't decay [17]. The composition and other details of the silica sand used in this research as follows, Near white, high purity and round shaped silica sand (AFS $60-65$ ) is available locally in New Zealand. Its bulk density is $1.55 \mathrm{~g} / \mathrm{cm} 3$ and the clay content is $0.35 \%$. Its other chemical properties are given in Table 1.

Gypsum is a natural mineral which has the formula $\mathrm{Ca}$ (SO4).2(H2O). Gypsum is a soft, transparent or translucent mineral composed of crystallized calcium sulphate (CaSO4), found naturally primarily in sedimentary deposits. In the chemically pure form, gypsum contains $23.28 \%$ calcium (Ca) and $18.62 \%$ sulfur $(\mathrm{S})$ in the readily available sulfate form (SO4). The traditional application of gypsum and gypsum based compositions is in the field of construction mortars for masonry and plasters, gypsum blocks, panels, gypsum fiber products, ceiling components, etc. The gypsum setting substances have qualities, which determine their application in other industrial areas as well. The ability to produce complex configurations through preliminary moulded gypsum models on one hand and obtaining a smooth surface of the products, not requiring additional treatment, on the other hand, expands the scope of its application in metal casting and machine building [19]. The qualitative and semi-quantitative component composition of the gypsum (50microns) which is used in this research is given in Table 2. According to the silicate analysis, the chemical composition of gypsum as follows (in \%mass): $\mathrm{Si02}$ - 2.3; Ca - 19.7(CaS04 - 67.0); $\mathrm{Mg}$ - 4.5; $\mathrm{Al}-$ 1.7(A1203 - 3.0); Fe - 0.8. The hygroscopic moisture content was $0.7 \%$; hydration water $-5.5 \%$; heating losses at $1000^{\circ} \mathrm{C}-9.0 \%$; fine rate of grinding $-4.2 \%$.

A.V. Koltygin [16] and R. Hayverova et al [18] were used gypsum as a powder binder; there is no information about the strength behavior at various conditions, this research aimed to address the same when the gypsum is mixed with 
silica sand. The 550W with 10 speed mixer was used to mix the composition for 10mins in order to coat the gypsum over the silica sand particles. A preliminary study conducted with varying percentage compositions of silica sand $(50 \%$ $90 \%)$, gypsum $(10 \%-50 \%)$ and moisture $(1 \%-15 \%)$ to select the right proportions. Test specimens were printed as per the CAD file to check their swelling effect, dimensional stability and by palm pressure breaking test. Based on the results obtained the right proportions has been selected to print test moulds to study the behavior of both mould and the cast part.

\section{EXPERIMENTS, RESULTS \& DISCUSSION}

Based on the results obtained by a preliminary test, to study further of the selected candidate mixture system in a systematic manner there were five rectangular specimens printed to check their dimensional stability and the density porosity relations in detail. $\mathrm{Z}$ printer 310 plus from $\mathrm{Z}$ Corporation was used to print those rectangular specimens with the dimensions of $4 \mathrm{~cm} \times 2 \mathrm{~cm} \times 1 \mathrm{~cm}$ shown in Fig1.

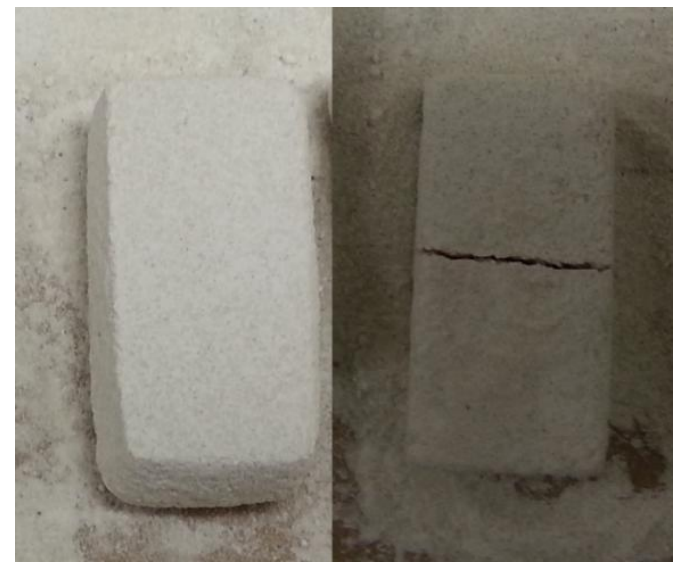

Fig-1: Strength Tested Specimens before and after baking

The composition for the selected candidate mixture is Industrial silica sand $65.36 \%$ and gypsum plaster $32.68 \%$ and water $1.96 \%$.

It was observed no problem of the powder spread system, any stair case effect or seepage of liquid binder when it hits the top surface of the powder layer while printing. The printed specimens allowed to dry inside the build chamber for $2 \mathrm{hrs}$ before it was taken out to measure the dimensions and the green weight; values are recorded in the Table 3. These specimens were baked in the furnace at $200{ }^{\circ} \mathrm{C}$ for $2 \mathrm{hrs}$ and allowed it to cool down in the furnace itself to avoid sudden exposure to atmosphere which may leads to absorbing the moisture which affect the properties, the dimensions and the weights were measured and the values were recorded in Table 4.

The density of the mould is directly proportional to the shape and size of the sand particles and the liquid binder. When the density increases the strength of the mould increases and the porosity decreases, which may lead to casting defects. Porosity or permeability is the ability of the mould allowing hot gases to escape when the molten metals is poured to the cavity, when the porosity increase the strength of the mould decreases. Therefore these two are must be balanced for quality casting. The density and porosity in percentage were calculated before and after baking the specimens. Theoretical and Experimental bulk density before baking is $2.14 \mathrm{~g} / \mathrm{cm} 3$ and $1.3 \mathrm{~g} / \mathrm{cm} 3$ respectively and the density difference is $0.84 \mathrm{~g} / \mathrm{cm} 3$. The percentage of theoretical and experimental porosity before baking is $19.24 \%$ and $50.94 \%$ respectively and the percentage difference is $31.7 \%$. Theoretical and Experimental bulk density after baking is $1.85 \mathrm{~g} / \mathrm{cm} 3$ and $1.74 \mathrm{~g} / \mathrm{cm} 3$ respectively and the difference is $0.11 \mathrm{~g} / \mathrm{cm} 3$. Theoretical and Experimental porosity after baking is $30.18 \%$ and $34.34 \%$ respectively and the percentage difference is $4.16 \%$. The difference between theoretical and experimental bulk density before and after baking is 0.29 $\mathrm{g} / \mathrm{cm} 3$ and $0.44 \mathrm{~g} / \mathrm{cm} 3$ respectively. The percentage difference of theoretical and experimental porosity before and after baking is $10.94 \%$ and $16.6 \%$ respectively. After baking, the value of experimental porosity is close to the value of theoretical porosity and the difference is just $4.16 \%$ whereas before baking this difference is $31.7 \%$. The result shows the importance of the calcination and the relation between the density and porosity, when density increases the mould strength increases but the porosity decreases.

T able-l: Chemical composition of Silica S and [18]

\begin{tabular}{|c|c|c|c|c|c|c|c|c|}
\hline Components & $\mathrm{Si}$ & $\mathrm{Fe}_{2} \mathrm{O}_{3}$ & $\mathrm{Na}_{2} \mathrm{O}$ & $\mathrm{A} 1$ & $\mathrm{Ca}_{\mathrm{O}} \mathrm{O}$ & $\mathrm{K}_{2} \mathrm{O}$ & $\mathrm{M}$ oisture & L 0I \\
\hline$\%$ & 99.32 & 0.07 & 0.02 & 0.16 & 0.10 & 0.10 & 0.10 & 0.20 \\
\hline
\end{tabular}

T ab le-2: Component composition of G ypsum [19]

\begin{tabular}{|c|c|c|c|c|c|c|c|c|c|c|c|c|c|}
\hline $\mathrm{Ca}_{\mathrm{a}}$ & $\mathrm{Si}$ & $\mathrm{Mg}$ & $\mathrm{Fe}$ & $\mathrm{A} 1$ & $\mathrm{Mn}$ & $\mathrm{Pb}$ & $\mathrm{Ni}$ & $\mathrm{Cr}$ & $\mathrm{Ti}$ & $\mathrm{Ba}$ & $\mathrm{Sr}_{\mathrm{r}}$ & $\mathrm{Na}$ & $\mathrm{Cu}$ \\
\hline$>5$ & $? 3$ & $>1$ & $=1$ & $=1$ & $=0,01$ & $? 10^{-5}$ & $? 10^{-5}$ & $=10^{-5}$ & $=10^{-2}$ & $=10^{-3}$ & $=1$ & $=0.03$ & $=10^{-4}$ \\
\hline
\end{tabular}


Table-3: Physical properties of the Rectangular specimens before baking.

\begin{tabular}{|c|c|c|c|c|c|c|}
\hline $\begin{array}{c}\text { Specimen } \\
\text { No. }\end{array}$ & \multicolumn{3}{|c|}{ Dimensions cm } & \multirow{2}{*}{$\begin{array}{c}\text { Volume } \\
\mathbf{c m}\end{array}$} & $\begin{array}{c}\text { Mass } \\
\mathbf{g}\end{array}$ & $\begin{array}{c}\text { Density } \\
\mathbf{g} / \mathbf{c m}^{\mathbf{3}}\end{array}$ \\
\cline { 2 - 4 } & $\mathbf{L}$ & $\mathbf{W}$ & $\mathbf{H}$ & 11.8 & 15 & 1.27 \\
\hline 1 & 4.3 & 2.3 & 1.2 & 1.2 & 16.8 & 1.33 \\
\hline 2 & 4.4 & 2.4 & 1.2 & 12.6 & 17.9 & 1.32 \\
\hline 3 & 4.5 & 2.5 & 1.2 & 13.5 & 18.2 & 1.22 \\
\hline 4 & 4.6 & 2.5 & 1.3 & 14.91 & 18 & 1.39 \\
\hline 5 & 4.5 & 2.4 & 1.2 & 12.9 & 17.18 & 1.3 \\
\hline Average & 4.46 & 2.42 & 1.22 & 13.16 & 17 & \\
\hline
\end{tabular}

Table-4: Physical properties of the Rectangular specimens after baking

\begin{tabular}{|c|c|c|c|c|c|c|}
\hline $\begin{array}{c}\text { Specimen } \\
\text { No. }\end{array}$ & \multicolumn{3}{|c|}{ Dime nsions cm } & \multirow{2}{*}{$\begin{array}{c}\text { Volume } \\
\mathbf{c m}^{\mathbf{3}}\end{array}$} & $\begin{array}{c}\text { Mass } \\
\mathbf{g}\end{array}$ & $\begin{array}{c}\text { Density } \\
\mathbf{g} / \mathbf{c m}^{\mathbf{3}}\end{array}$ \\
\hline & $\mathbf{L}$ & $\mathbf{W}$ & $\mathbf{H}$ & 8.28 & 13.5 & 1.63 \\
\hline 1 & 4 & 2.01 & 1.03 & 8.03 & 14.7 & 1.78 \\
\hline 2 & 4 & 2 & 1.03 & 8.24 & 15 & 1.8 \\
\hline 3 & 4 & 2.01 & 1.03 & 8.28 & 15.9 & 1.85 \\
\hline 4 & 4.02 & 2.01 & 1.06 & 8.56 & 15.1 & 1.61 \\
\hline 5 & 4.06 & 2.09 & 1.1 & 9.33 & 14.84 & 1.74 \\
\hline Average & 4.02 & 2.02 & 1.05 & 8.52 & \multicolumn{2}{c}{} \\
\hline
\end{tabular}

Table-5: Average Swelling, Shrinkage and Volume Error

\begin{tabular}{|c|c|c|c|c|c|c|c|c|c|c|c|c|c|c|c|c|}
\hline $\begin{array}{c}\text { Actual } \\
\text { Dimensions } \\
(\mathrm{cm})\end{array}$ & \multicolumn{2}{c|}{$\begin{array}{c}\text { Average } \\
\text { Dimensions } \\
\text { BB (cm) }\end{array}$} & \multicolumn{2}{c|}{$\begin{array}{c}\text { Average } \\
\text { Dimensions } \\
\text { AB (cm) }\end{array}$} & \multicolumn{2}{c|}{$\begin{array}{c}\text { Average } \\
\text { Swelling Error } \\
\text { BB (\%) }\end{array}$} & \multicolumn{3}{c|}{$\begin{array}{c}\text { Average } \\
\text { Shrinkage } \\
\text { Error AB (\%) }\end{array}$} & $\begin{array}{c}\text { Average } \\
\text { Volume } \\
\text { Error (\%) }\end{array}$ \\
\hline L & W & H & L & W & H & L & W & H & L & W & H & L & W & H & BB & AB \\
\hline 4 & 2 & 1 & 4.46 & 2.42 & 1.22 & 4.02 & 2.02 & 1.05 & 11.5 & 21 & 22 & 0.5 & 1 & 5 & 64.5 & 6.5 \\
\hline
\end{tabular}

Where, L - Length, W- Width, H- Height, BB- Before Baking, AB- After Baking

The linear shrinkage of the material would be compensated by giving extra allowances however the shrinkages in sand moulds can be controlled by adding suitable binders, additives and moisture level. The swelling and shrinkage errors were calculated for the printed specimen before and after baking, the values are tabulated in Table 5. The dimensional error analyses of the samples shows the percentage swelling and shrinkage errors which is nonlinear, if it is linear the percentage difference would be added in the mould design or it would be adjusted in the $\mathrm{z}$ printer software, but the result shows $0.5 \%$ shrinkage in lateral axis, $1 \%$ in horizontal axis, and $5 \%$ in vertical axis. Based on the volume the average error is been drastically reduced from $64.5 \%$ to $6.5 \%$. These result shows that the mould shrinkage can be reduced by further optimizing the baking condition and or adding of additives like polyacrylate [18] and this would be implemented in the future experiments.

The commercial Z Cast 501 material system recommends $12 \mathrm{~mm}$ minimum as wall thickness for shell moulds [11]. An attempt was made to print nine shell moulds with a wall thickness of $10 \mathrm{~mm}$ as per the arrangement given in the Table 6.

Table-6: Arrangement for the printing of 9 test moulds

\begin{tabular}{|l|l|l|l|l|}
\hline \multirow{2}{*}{$\begin{array}{l}\text { Bake } \\
\text { Temperature }\end{array}$} & \multirow{2}{*}{$\begin{array}{l}\text { Bake } \\
\text { Time }\end{array}$} & \multicolumn{4}{|l|}{ Type of Coating } \\
\cline { 3 - 5 } & & $\begin{array}{l}\text { No } \\
\text { Coating }\end{array}$ & Zircon & $\begin{array}{l}\text { Sodium } \\
\text { Silicate }\end{array}$ \\
\hline $200^{\circ} \mathrm{C}$ & $2 \mathrm{hrs}$ & 1 & 1 & 1 \\
\hline $400^{\circ} \mathrm{C}$ & $2 \mathrm{hrs}$ & 1 & 1 & 1 \\
\hline $600{ }^{\circ} \mathrm{C}$ & $2 \mathrm{hrs}$ & 1 & 1 & 1 \\
\hline Pouring Temperature & $850{ }^{\circ} \mathrm{C}$ & $900^{\circ} \mathrm{C}$ & $950{ }^{\circ} \mathrm{C}$ \\
\hline
\end{tabular}

It was quiet interesting to see the printed moulds having enough handling green strength shown in Fig 2. Three different temperature conditions were chosen to steady the baking temperature influences namely $200^{\circ} \mathrm{C}, 400^{\circ} \mathrm{C}$ and $600^{\circ} \mathrm{C}$ for $2 \mathrm{hrs}$ to retreat of the moisture prior to cast. Two different types of coating of CMS Zircoat W and Sodium silicate were diluted to $50 \%$ with water used to coat the 6 test moulds. Diluted Zircoat W was coated by brush (Fig 3); there was a chance for an uneven coating layer which is 
directly related to the surface roughness and coat of diluted sodium silicate was not shown in the figure. An Aluminum alloy grade of $\mathrm{Al} 6351 \mathrm{~T} 6$ was cast at three different melting temperatures say $850^{\circ} \mathrm{C}, 900^{\circ} \mathrm{C}$ and $950^{\circ} \mathrm{C}$ shown in Fig 4 . When the molten metal passed half the time of its solidification there were small cracks developed outside the cavity, runner and riser funnels. After few more minutes the riser funnel from another mould was broken completely (Fig4), but no leakage of the molten metal or any other distortion observed on cast part, even there was no brake or bigger cracks observed on the cavity side of the same mould, the reason would be porosity and the bonding strength of the funnel and the mass of the molten metal inside the riser funnel.

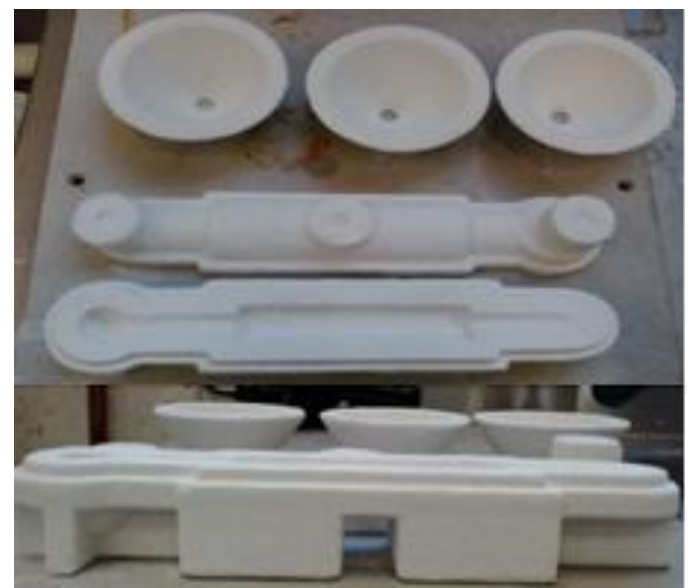

Fig-2: Printed Moulds before and after baking

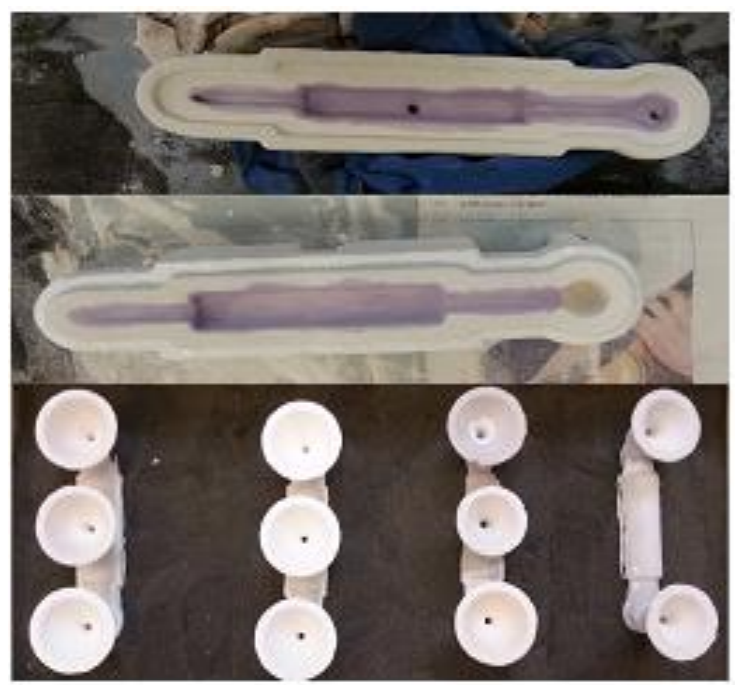

Fig-3: Mould Coated with Zirconium

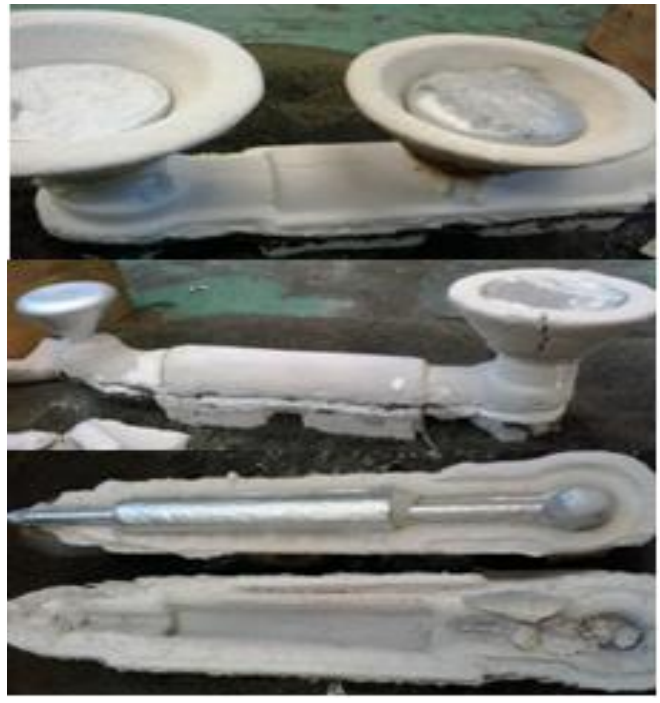

Fig-4: Mould and Cast after Solidification

Except the surface roughness there were no other casting defects like mould wash, mould burn or distortion, and etc. (Fig 4). It shows that the gypsum bonded mould have enough mould strength for casting at various conditions. In general surface roughness is the main concern in sand casting, it can be improved by adding suitable additives and coatings. The Surface roughness of casting is influenced by various factors such as method of casting, type of moulds, size and shape of the sand particles, additives used, method of compaction, type of alloy, Pouring temperature of molten metal, etc. The finer the sand used, the better the surface finish. However, fine sand limits permeability, which can create casting defects. And alloys with higher melting points produce lower RMS values than alloys with lower melting points. In other words, iron castings will not be as smooth as aluminum castings, and steel castings typically will be rougher still. Coatings fill the voids between sand grains and can also act as a refractory, limiting the defects and loss of integrity that can occur with higher melting point alloys [20]. From Taylor Hobson, Talysurf 50 surface roughness tester was used to measure the RMS values on the cast parts. Measured values are tabulated in Table 7.

Table-7: Surface Roughness Test results

\begin{tabular}{|l|l|l|l|}
\hline $\begin{array}{l}\text { Mould } \\
\text { Baking } \\
\text { Condition }\end{array}$ & $\begin{array}{l}\text { No- } \\
\text { coating }\end{array}$ & $\begin{array}{l}\text { Zirconium } \\
\text { Coated }\end{array}$ & $\begin{array}{l}\text { Sodium } \\
\text { Silicate } \\
\text { coated }\end{array}$ \\
\hline $200^{\circ} \mathrm{C}$ & $41.57 \mu \mathrm{m}$ & $24.35 \mu \mathrm{m}$ & $37.77 \mu \mathrm{m}$ \\
\hline $400^{\circ} \mathrm{C}$ & $32.94 \mu \mathrm{m}$ & $34.23 \mu \mathrm{m}$ & $43.12 \mu \mathrm{m}$ \\
\hline $600^{\circ} \mathrm{C}$ & $47.12 \mu \mathrm{m}$ & $33.71 \mu \mathrm{m}$ & $29.25 \mu \mathrm{m}$ \\
\hline
\end{tabular}

The lowest surface roughness value is obtained with the combination of mould coated with diluted Zirconium, the lowest baking temperature of $200^{\circ} \mathrm{C}$ and the pouring temperature is $900^{\circ} \mathrm{C}$. The coating was done conventionally by brush; there are chances to get better surface finish if the coating is done professionally. The highest value is recorded against the no-coating and the highest baking temperature; since the mould was baked at $600^{\circ} \mathrm{C}$ the voids would have increased the porosity in the cavity. The measured value 
with coating $24.35 \mu \mathrm{m}$ and without coating $32.94 \mu \mathrm{m}$ is lesser than the RMS value of $46.81 \mu \mathrm{m}$ bench mark measured value of Zcast 501 and the traditional sand casting, without any coating, RMS value range of 75-150 $\mu \mathrm{m}$ for shell moulding [20]. From the above result it is understood that the baking temperature and the type of coating influencing the surface roughness. The RMS value clearly states that the locally available material system is capable of producing superior surface finish when it's incorporated with three dimensional printing. Seeing the (Fig 5) result of Surface roughness, moulds No coating increases the surface roughness values while increasing the baking temperature, mould with zirconium coating decreases the surface roughness values while decreasing the baking temperature, mould with sodium silicate coating decreases the value of the surface roughness while the baking temperature increases.

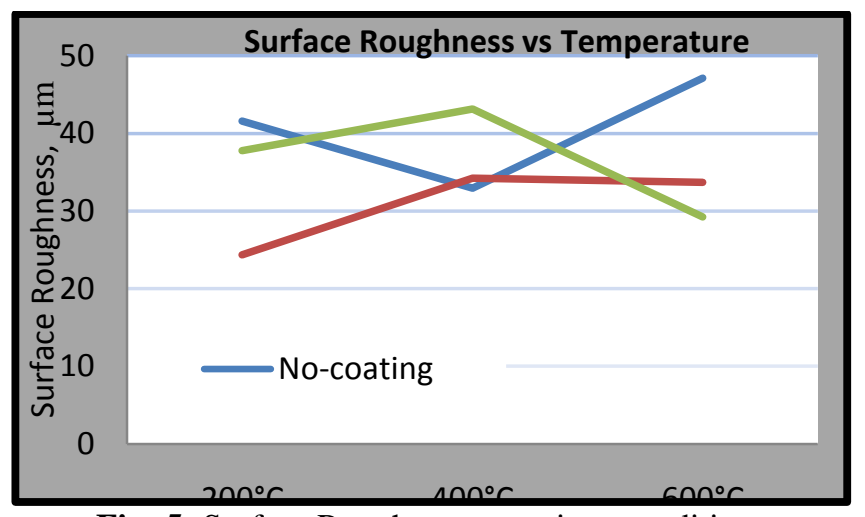

Fig- 5: Surface Roughness at various conditions

The cast parts were machined as per the ASTM B557 standard shown in Fig 6 to measure the tensile strength of the cast parts and the values are recorded in Table 8 . The highest Tensile strength $135.1 \mathrm{MPa}$ was measured with the combination of mould no-coating, baked and poured with lowest temperature $200^{\circ} \mathrm{C}$ and $850^{\circ} \mathrm{C}$ respectively. On the other hand the lowest strength values is measured against highest baking temperature and coated with sodium silicate. From the result, baking temperature, Zirconium, and Sodium Silicate coating have no influence in the tensile strength. Since the Al 6351 Aluminum alloy is a brittle in nature no neck formation before fracture. The cast $6351 \mathrm{Al}$ alloys' strength and ductility is very low, the UTS is $119 \mathrm{MPa}$ by sand casting, Usually Al 6351 alloy possess poor cast ability and the alloy is used in wrought form [21, 22].

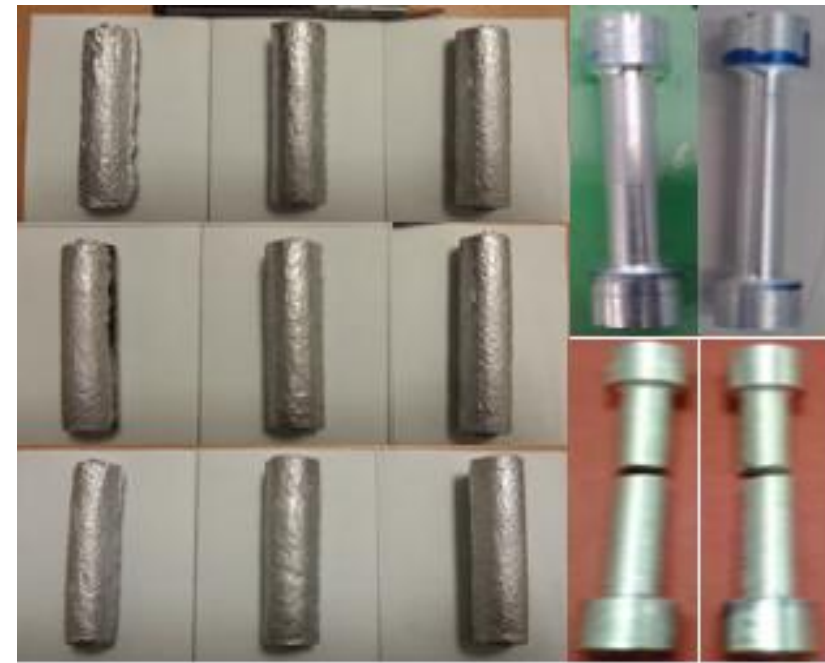

Fig-6: Cast parts and Tensile strength test specimens

Table-8: Ultimate Tensile Strength values of the cast parts

\begin{tabular}{|l|l|l|l|}
\hline $\begin{array}{l}\text { Mould } \\
\text { Baking } \\
\text { Condition }\end{array}$ & $\begin{array}{l}\text { No- } \\
\text { coating }\end{array}$ & $\begin{array}{l}\text { Zirconium } \\
\text { Coated }\end{array}$ & $\begin{array}{l}\text { Sodium } \\
\text { Silicate } \\
\text { coated }\end{array}$ \\
\hline $200^{\circ} \mathrm{C}$ & $135.1 \mathrm{MPa}$ & $121.1 \mathrm{MPa}$ & $96.0 \mathrm{MPa}$ \\
\hline $400^{\circ} \mathrm{C}$ & $103.5 \mathrm{MPa}$ & $124.0 \mathrm{MPa}$ & $84.5 \mathrm{MPa}$ \\
\hline $600^{\circ} \mathrm{C}$ & $119.4 \mathrm{MPa}$ & $120.4 \mathrm{MPa}$ & $73.3 \mathrm{MPa}$ \\
\hline
\end{tabular}

Since the Al 6351 Aluminum alloy is a brittle in nature no neck formation before fracture. The cast 6351 Al alloys' strength and ductility is very low, the UTS is $119 \mathrm{MPa}$ by sand casting, Usually Al 6351 alloy possess poor castability and the alloy is used in wrought form [21, 22]. Another bench marked measured tensile strength value from Zcast mould is $89.8 \mathrm{MPa}$. Compare with two bench marked values the gypsum bonded mould produced cast part tensile strength value is higher and it's proved that the locally available material systems can be used to print moulds by 3DP and is not an inferior with other systems.

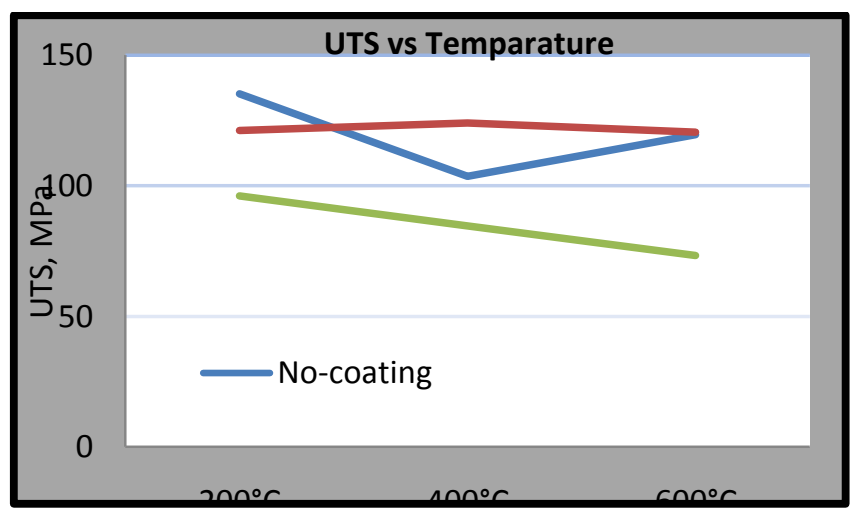

Fig-7: Tensile Strength values at various conditions

Seeing the(Fig 7) result of UTS, mould no -coating decreases while the baking temperature increases, mould coated with zirconium has little effect on UTS while the baking temperature increases, mould coated sodium silicate decreases the UTS value while the baking temperature increases. 


\section{CONCLUSIONS}

The locally available gypsum and silica sand material systems used in this project has shown great potential as material system for 3DP process to produce sand moulds for Non-ferrous castings. Even though it has a shrinkage percentage error of $6.5 \%$ it can be controlled by adding a suitable additives or fine tuning the baking parameter. Since the mould is been baked it is easy to control the moisture content which results porosity and related void fraction. Result of surface roughness and tensile strength shows that the gypsum bonded mould possesses adequate strength, refractoriness and cohesiveness which are essential characteristics of any moulding sand. There were no signs of Open Blows and Blow Holes, Cracked Casting, Dropped Mould, Fusion, Swell, Run out, Mismatch, Inclusions, Cuts and Washes, Metal penetration, Hard Spots, Scabs and etc. The result of the tensile strength value of $135.1 \mathrm{MPa}$ which is higher and the measured surface roughness value with coating $24.35 \mu \mathrm{m}$ and without coating $32.94 \mu \mathrm{m}$ are lesser than the bench marked values shows that the local materials can be used in 3DP system to print moulds for Non-Ferrous casting. Even though the results are satisfactory at laboratory level, the strength of the mould has to be increased further by adding other suitable binders and additives and needs to be investigated the other moulding sand properties considering various influencing factors before it go into a real time environment.

\section{REFERENCES}

[1] Feridun Boylu., Optimization of foundry sand characteristic of soad-activated calcium bentonite, Applied Clay Science, 2011, 52, p104-108

[2] Prof. Dr. Turkeli , A. (2009). Sand Casting. Istanbul, Turkey

[3] www.jade-trading.com

[4] www.afsinc.org/content.cfm?ItemNumber=7613

[5] T. Wohlers, Future potential of rapid prototyping and manufacturing around the world, Rapid prototyping Journal 1 / 1 (1995), 4-10.

[6] E.M. Sachs, J. S Haggerty, M.J Cima, A.P Wiliams, Three Dimensional Printing Techniques, United States Patent no. US 005340656 (1994).

[7] S. Ashley, From CAD art tot rapid metal tools, Mechanical Engineering 3 (1997),82-87.

[8] Bobby. S., Singamneni S., Conformal cooling through thin shell moulds produced by 3Dp printing, Australian Journal of Multi-Diciplinary Engineering, June 2013, vol 9 (2), 155-163.

[9] R. Singh, M. Verma., Investigations for deducing wall thickness of aluminium shell casting using three dimensional printing, Journal of Achievements in Materials and Manufacturing Engineering, Vol 31, (2), 2008, 565-569.

[10] www.exone.com / European patent / 2009

[11] Z Corporation / Direct Metal casting design guide/ 2004

[12] Nicholas mc Kenna, Rapid Casting, Master Thesis, AUT university, 2008.
[13] Koltygin, A.V., Gorbuzova, I.V., Abramova,T.I., and Bazhenov, V.E., Litein. Proizvod., 2010,no.6, p 30

[14] Brechko, A.A and Velikanov,G.F., Molding and Rod mixtures with specified properties, Leningrad, Mashinostroenie, 1982.

[15] Galdin, N.M., Chernega.D.F., Ivanchuk., NonFerrous Foundry: Hand Book, Moscow, Mashinostroenie, 1989.

[16] A.V. Koltygin, V.E.Bazhenov., Development of a Substiute for $\mathrm{Z}$ cast moulding sand used on Installations of 3D printing for obtaining Aluminium, Magnesium, and Iron casting, Russian Journal of Non-Ferrous Metals, 2012, Vol 53, (1), 38-41.

[17] Frondel C., Dana's System of Mineralogy, $7^{\text {th }}$ Edition, 1962.

[18] www.Industrialsands.co.nz

[19] R. Hayverova., N. Kasabova., "Gypsum composition for preparing moulds and models based on local raw materials" Journal of the University of Chemical Technology and Metallurgy, Vol 42 (4), 2007, 381386.

[20] http:www.afsinc.org/about/content.cfm?ItemNo6915

[21] Bijay Kumar Show., DipakKumarMondal., KoushikBiswas., Joy deep Maity., "Development of a novel 6351Al-(A14SiC4+SiC) hybrid composite with enhanced mechanical properties", Materials Science \& Engineering A 579 (2013)136-149.

[22] Application of Aluminium Alloys and Tempers, pp 97-98, (www.asmintrnatioanl.org/pdf/spotlight/6180/ pg87-118/web.pdf) 